\title{
Andrea Fasso, Il sogno del cavaliere. Chrétien de Troyes e la regalità
}

\section{Walter Meliga}

\section{(2) OpenEdition}

1 Journals

\section{Edizione digitale}

URL: http://journals.openedition.org/studifrancesi/35662

DOI: 10.4000/studifrancesi.35662

ISSN: 2421-5856

\section{Editore}

Rosenberg \& Sellier

\section{Edizione cartacea}

Data di pubblicazione: 1 juillet 2005

Paginazione: 128

ISSN: 0039-2944

\section{Notizia bibliografica digitale}

Walter Meliga, «Andrea Fasso, II sogno del cavaliere. Chrétien de Troyes e la regalità», Studi Francesi [Online], 145 (XLIX | I) | 2005, online dal 30 novembre 2015, consultato il 21 avril 2021. URL: http:// journals.openedition.org/studifrancesi/35662 ; DOI: https://doi.org/10.4000/studifrancesi.35662

Questo documento è stato generato automaticamente il 21 avril 2021.

\section{(c) (i) (9)}

Studi Francesi è distribuita con Licenza Creative Commons Attribuzione - Non commerciale - Non opere derivate 4.0 Internazionale. 


\title{
Andrea Fasso, Il sogno del cavaliere. Chrétien de Troyes e la regalità
}

\author{
Walter Meliga
}

\section{NOTIZIA}

ANDREA FASSO, Il sogno del cavaliere. Chrétien de Troyes e la regalità, con la collaborazione di Michela SALVINI, Roma, Carocci («Biblioteca Medievale. Saggi», 14), 2003.

1 Il volume raccoglie saggi, già editi separatamente, sull'opera di Chrétien de Troyes e in particolare sul primo romanzo Erec et Enide. L'assunto generale dell'autore è la considerazione del sogno come logica interna di questo come di altri romanzi di Chrétien e dell'inconscio come linguaggio narrativo. Elementi costitutivi di questa logica e di questo linguaggio sarebbero il meraviglioso, che ha così larga parte nei romanzi arturiani, e le contraddizioni e i rivolgimenti narrativi delle storie stesse. Il «sogno del cavaliere», una volta analizzato, permette di scoprire la situazione che sta alla base della condizione cortese e delle aventures che genera: il conflitto tra il cavaliere e il re e la sua aspirazione al potere, alla regalità, attraverso la conquista della regina (Ginevra) o di una sua sostituta (Enide). Il conflitto peraltro non è soltanto generatore di aventures cavalleresche, ma anche di una ricerca interiore, di un'educazione personale che rendono il romanzo cortese il modello del romanzo moderno. 